\title{
The effect of primiparous pregnant women's preferences for mode of delivery on their fear of childbirth and postpartum period
}

\author{
Dilek Bilgic*1, Șükran Ertekin Pınar², Gülseren Dağlar ${ }^{2}$, Büșra Cesur ${ }^{2}$ \\ ${ }^{1}$ Dokuz Eylül University Faculty of Nursing, Izmir, Turkey \\ ${ }^{2}$ Cumhuriyet University Faculty of Health Sciences, Sivas, Turkey
}

Received: August 30, 2018

DOI: $10.5430 /$ cns.v7n1p98
Accepted: December 7, 2018

URL: https://doi.org/10.5430/cns.v7n1p98

Online Published: December 28, 2018

\begin{abstract}
Aim is to examine the relationship between the primiparous pregnant women's preferences for mode of delivery and their fear of childbirth and postpartum period. This descriptive study's sample consisted of 211 primiparous pregnant women who applied to a state hospital's obstetrics and gynecology clinic for a check-up. Data were collected by Personal Information Form and Fear of Childbirth and Postpartum Period Scale (FCPPS) which includes questions for socio-demographic characteristics of individuals and questions related to preferences for mode of delivery. Percentage distribution, $t$ test, Kruskal Wallis analysis, one-way analysis of variance were used in the evaluation of the data, and the level of significance was determined as $p<.05$. $87.7 \%$ of pregnant women have stated that if they have a chance to choose, they will prefer vaginal delivery. FCPPS total mean score was $5.30 \pm 1.44$ and $49.8 \%$ of their fear was found to be at moderate level. There was no statistically significant difference between FCPPS subscale and total mean scores according to pregnant women's preferences for mode of delivery $(p>.05)$. Most of primiparous women stated their preference for mode of delivery as vaginal delivery. Pregnant women's fear of childbirth and postpartum period are at moderate level and their preferences for mode of delivery do not affect their fear of childbirth and postpartum period. Taking into consideration pregnant women's preferences for mode of delivery unless it requires medical indication, supporting their preferences, alleviating their fear of childbirth and postpartum period are extremely important in increasing their satisfaction and adaptation to pregnancy, childbirth and to postpartum period.
\end{abstract}

Key Words: Primiparous pregnant women, Preferences for mode of delivery, Vaginal delivery, Fear, Midwife, Nurse

\section{INTRODUCTION}

Pregnancy and childbirth are physiological processes in which many unnecessary interventions are made by the pressure of the developing technology over time and the woman does not play an effective role in this process. However, pregnancy is a natural, normal and healthy function of the body. The physiological structure of the female body is usually suitable for normal vaginal delivery, and if adequate support is provided and proper intervention is made, normal vaginal delivery can be successfully performed. The World Health Organization (WHO) has predicted that ideal caesarean rates should be between 10\% and 15\% since 1985 . Values above and below the recommended rate indicate that countries are at an increased risk of maternal/fetal mortality and morbidity rates. However, in recent years caesarean rates have continued to increase rapidly in developed and developing countries. ${ }^{[1]}$ In recent years, governments and

*Correspondence: Dilek Bilgic; Email: dilekbilgic44@gmail.com; Address: Dokuz Eylül University Faculty of Nursing, İzmir, Turkey. 
clinicians have expressed concern about the negative consequences of increased caesarean section for maternal and child health and indicated the need to reconsider caesarean rates recommended in 1985 .

The WHO also recommended the labor beginning on its own and avoidance of unnecessary interventions, and in this context the Coalition for Improving Maternity Services (CIMS) in $1996^{[2]}$ aimed at improving delivery results, reducing caesarean rates, reducing costs and identified five philosophical cornerstones of mother-friendly care which are normality of the birth process, empowerment, autonomy, not giving harm and taking responsibility. Therefore, rising rates in recent years have led to changes in countries' health policies and the regulation of practices that encourage vaginal delivery, which will affect people's views on birth and their birth preferences positively. ${ }^{[1]}$ In recent years, the Ministry of Health of Turkey has started to emphasize this issue and it has brought some regulations and sanctions (informing pregnants, mother-friendly hospitals, hospital and personal reports with requests for justifications, reduction of performance in caesarean practices) ${ }^{[3,4]}$ Whereas the ceaesarean section (CS) rates remain high in our country $(53 \%){ }^{[5]}$

One of the important issues to be decided during pregnancy is the decision of the mode of delivery. In the preference for mode of delivery, some factors such as friends, media, health professionals, effective antenatal care and fear of childbirth may affect the decision-making. ${ }^{[6-10]}$ Therefore, pregnant women can make a decision about the mode of delivery with the effect of these factors, sometimes they can give birth with a method different from their decisions intentionally or unintentionally. In the studies conducted, it is stated that female obstetricians have a role in the preference of caesarean section and they believe that in caesarean section women will face less risk for the baby and for themselves compared to a difficult vaginal delivery. ${ }^{[11-13]}$ In addition, pregnant women see caesarean section more controlled and safe, ${ }^{[14]}$ and they prefer caesarean section to not to experience negative birth experience. ${ }^{[14]}$ Pregnant women may prefer caesarean section due to false beliefs and perceptions (fear of painful vaginal delivery, birth asphyxia, adversely affected postpartum sexual life etc.). ${ }^{[10,15-17]}$

In some international studies, it has been shown that $0.3 \%$ $14 \%$ of women prefer caesarean section willingly. ${ }^{[18,19]}$ In the majority of the studies, it has been found that women with caesarean section have some medical/psychological/obstetric problems, and few women prefer surgical delivery even though they do not require any indication. ${ }^{[20,21]}$ Fear of childbirth may be a factor in women's preference of a caesarean who do not have any medical indication (e.g. psychosocial

Published by Sciedu Press indications). ${ }^{[22,23]}$ In the literature, especially nulliparous women has more fear of childbirth than multiparous women, and thus there are many studies showing that caesarean section is preferred. ${ }^{[24,25]}$ If the proper care is given to women who have fear of childbirth by health professionals, their fear of birth may be reduced. To reduce the fear of childbirth, women should be considered from the moment they plan to conceive and care should continue during pregnancy and childbirth. ${ }^{[26]}$

The preferred or decided mode of delivery can cause anxiety about how the woman or her baby will be affected and what the consequences will be. ${ }^{[27]}$ In addition, health of the baby is the most important issue during pregnancy and most women want a birth which is the safest for the baby. Maternal safety, postpartum fast recovery and breastfeeding are among the most important issues mentioned by women, with other significant concerns. ${ }^{[28-31]}$ Helping the pregnant woman to decide the right mode of delivery with the right and adequate information, relieving her anxiety and fear, allowing her family to participate more consciously in the decision making process can help to end up with a healthy mother and baby while facilitating the adaptation to pregnancy and birth process.

Investigating pregnant women's preferences for mode of delivery and determining their fears and worries in this context will enable the elimination of the concerns and fears related to the prenatal birth preferences. Eliminating concerns about preferences will contribute to the decrease in preference for caesarean section and the increase in preference for vaginal delivery. Fear of childbirth, labor pain, birth complications, duration of delivery, oxytocin use, newborn complications and post-partum psychological problems can decrease. In addition, feeling of being ready for birth increases, adaptation and satisfaction with childbirth increase, mother-infant relationship is strengthened and breastfeeding is positively affected. ${ }^{[26,32]}$

Aim in this study is to examine the relationship between the primiparous pregnant women's preferences for mode of delivery and their fear of childbirth and postpartum period.

\section{Methods}

\subsection{Research type}

This study was conducted as a cross-sectional descriptive study to examine the relationship between the primiparous pregnant women's preferences for mode of delivery and their fear of childbirth and postpartum period. The research was conducted in a state hospital's obstetrics and gynecology clinic located in the Central Anatolia Region of Turkey between March 15 and October 2014. 


\subsection{Research population/sample}

The population of the study consisted of primiparous pregnant women who applied to a state hospital's obstetrics and gynecology clinic located in the Central Anatolia Region of Turkey between March 15 and October 2014.

The sample size used in this study was calculated by using power analysis. According to the literature, it was found that $20 \%$ of pregnant women had fear of birth. ${ }^{[33]}$ Sample size for the population was designated at $\alpha=0.05$ significance level, $1-\alpha=0.95$ confidence interval, $\beta=0.20$ error risk and $1-\beta=0.80$ power and total number of people was 211 . The sample of the study consisted of 211 primiparous pregnant women who applied to a clinic between these dates, who had no health problem, communication and perception error and who agreed to participate in the study. 40 primiparous pregnant women due to having risky pregnancy, 50 primiparous pregnant women due to not agreeing to participate in the study, 45 primiparous pregnant women due to not completing the questionnaire, and 25 primiparous pregnant women due to having communication problems were not included in the study.

\subsection{Data collection tools}

Data were collected by Personal Information Form and Fear of Childbirth and Postpartum Period Scale (FCPPS) ${ }^{[33]}$ which includes questions for socio-demographic characteristics of individuals and questions related to preferences for mode of delivery. Personal Information Form, The form created by the researchers is composed of two parts. In the first part, there are 20 questions related to the socio-demographic and obstetric characteristics of the individuals. The second part consists of 26 questions about the preferences for mode of delivery, reasons for preferring vaginal delivery and caesarean section.

The scale designed for the Turkish population by Kitapçığlu et al. ${ }^{[33]}$ consists of 61 expressions that determine the fears of women during pregnany and postpartum period. The scale is 5-point likert type. For each expression, a minimum of 1 and a maximum of 5 points are given. "Strongly disagree" 1 point, "Disagree" 2 points, "Undecided" 3 points, "Agree" 4 points, "Strongly agree" is 5 points. The scale consists of 10 subscales which are "fears related to baby", "fears related to labor", "fears related to breastfeeding", "fears of being insufficient in postpartum infant care", "fears related to postpartum social life", "fears related to postpartum infant and puerpera health", "fears of not having support from the partner", "fears related to antenatal period", "fears related to behaviors of health professionals during pregnancy" and "fear of caesarean section". The highest score possible from the scale is 10 , the lowest score is 0 . There are no inversely scored expressions in the scale. Points after standardization are 0.00-2.00: Very low, 2.01-4.00: Low, 4.01-6.00: Medium, 6.01-8.00: High and 8.01-10.00: Very high. The Cronbach Alpha value of the scale was 0.95 in the validity and reliability study. In this study, the Cronbach Alpha value was 0.96 . Questionnaires were filled out by researchers by interviewing pregnant women face to face. The questionnaires took approximately 10-15 minutes to fill out.

\subsection{Ethical aspect}

Before the study, approval was obtained from the Local Medical Research Ethics Committee and from the hospital where the research was conducted. The consents of the pregnant women, who agreed to participate in the research after explaining the purpose of the study, were taken and the research was conducted according to the Helsinki Declaration.

\subsection{Statistical analysis}

The data obtained from the study were evaluated in the SPSS 14 package program. Percentage distribution, $t$ test, one way ANOVA and Kruskal Wallis analysis were used in the analysis of the data and the significance level was taken as $p<$ .05 .

\section{Results}

As shown in Table 1, the mean age of pregnant women is $23.62 \pm 3.73$, the mean gestational week is $33.10 \pm 5.83$. $52.6 \%$ of pregnant women are between $23-29$ years, $46.4 \%$ are primary school graduates, $82.0 \%$ do not work, $82.9 \%$ live in the city center, $69.7 \%$ live in nuclear family, $65.9 \%$ have equal income and expense, $87.7 \%$ have social security, and $89.6 \%$ of them do not smoke (see Table 1).

As shown in Table 2, 83.4\% of pregnant women had spontaneous pregnancy, $77.7 \%$ had planned pregnancy and $96.7 \%$ had wanted pregnancy. $95.7 \%$ of pregnant women stated that they went to regular check-ups during pregnancy, $59.2 \%$ got information about modes of delivery $(25.1 \%$ from physicians, $11.4 \%$ from environment and mass media, $26.5 \%$ from midwives/nurses) and $81.5 \%$ wanted to be informed about modes of delivery. It was found that $87.7 \%$ of pregnant women stated that they would prefer vaginal delivery if they had a chance to choose (see Table 2).

As shown in Table 3, pregnant women have stated that they will prefer vaginal delivery because "it is healthier for mother and infant (85.3\%)", "they will recover more quickly after birth $(83.9 \%)$ ", "it would be more natural and non-interventional (80.6\%)", "the baby will start to breastfeed earlier (77.7\%)", "they will have less pain after birth (76.8\%)", "it will be safer for mother and infant (79.6\%)" and "being afraid of caesarean section/surgery (40.3\%)" (see 
Table 3).

Table 1. Characteristics of pregnant women $(n=211)$

\begin{tabular}{|c|c|c|}
\hline & $\mathbf{n}$ & $\%$ \\
\hline \multicolumn{3}{|l|}{ Age } \\
\hline $17-22$ & 86 & 40.8 \\
\hline $23-29$ & 111 & 52.6 \\
\hline $30-36$ & 14 & 6.6 \\
\hline \multicolumn{3}{|l|}{ Educational Level } \\
\hline Primary school & 98 & 46.4 \\
\hline High school & 53 & 25.1 \\
\hline University and above & 60 & 28.4 \\
\hline \multicolumn{3}{|l|}{ Working Status } \\
\hline Working & 38 & 18.0 \\
\hline Not working & 173 & 82.0 \\
\hline \multicolumn{3}{|l|}{ Residence Place } \\
\hline Province & 175 & 82.9 \\
\hline District & 21 & 10.0 \\
\hline Village/town & 15 & 7.1 \\
\hline \multicolumn{3}{|l|}{ Family Type } \\
\hline Nuclear & 147 & 69.7 \\
\hline Extended & 64 & 30.3 \\
\hline \multicolumn{3}{|l|}{ Perception of financial status } \\
\hline Income less than expense & 49 & 23.2 \\
\hline Income equal to expense & 139 & 65.9 \\
\hline Income more than expense & 23 & 10.9 \\
\hline \multicolumn{3}{|l|}{ Social security } \\
\hline Yes & 185 & 87.7 \\
\hline No & 26 & 12.3 \\
\hline \multicolumn{3}{|l|}{ Smoking } \\
\hline Yes & 22 & 10.4 \\
\hline No & 189 & 89.6 \\
\hline
\end{tabular}

As shown in Table 4, pregnant women stated that they would prefer caesarean section because "being afraid of labor pain and thinking that caesarean section will be less painful (73.3\%)", "birth will take place in more clean and sterile conditions $(73.3 \%)$ ), "caesarean section causes less vaginal damage (73.3\%)", "caesarean section is easier than vaginal delivery $(66.7 \%)$ ", "caesarean is safer and healthier for the mother $(60 \%)$ ", "caesarean section does not affect later sexual life (60\%)" and "caesarean section is safer and healthier for the baby (53.3\%)" (see Table 4).

FCPPS total mean score is $5.30 \pm 1.44$. Of subscales, fears related to baby mean score is $4.35 \pm 1.76$, fears related to labor mean score is $6.12 \pm 1.92$, fears related to breastfeeding mean score is $6.03 \pm 2.23$, fear of being insufficient in postpartum infant care mean score is $5.22 \pm 2.02$, fears related to postpartum social life mean score is $4.30 \pm 1.97$, fears related to postpartum infant and puerpera health mean score is $5.09 \pm 1.82$, fear of not having support from the partner mean score is $3.77 \pm 1.78$, fears related to antenatal period mean score is $5.64 \pm 2.19$, fears related to behaviors of health professionals during pregnancy mean score is 6.46 \pm 2.36 and fear of having caesarean section mean score is $6.06 \pm 2.48$.

Table 2. Obstetric characteristics of pregnant women $(n=$ 211)

\begin{tabular}{lcc}
\hline & n & \% \\
\hline Type of pregnancy & 176 & 83.4 \\
$\quad$ Spontaneous & 35 & 16.6 \\
$\quad$ Treatment & & \\
Planned pregnancy & 164 & 77.7 \\
$\quad$ Planned & 47 & 22.3 \\
$\quad$ Unplanned & & \\
Wanted pregnancy & 204 & 96.7 \\
$\quad$ Yes & 7 & 3.3 \\
$\quad$ No & & \\
Regular check-ups & 202 & 95.7 \\
$\quad$ Yes & 9 & 4.3 \\
$\quad$ No & & \\
Having information about modes of delivery & \\
$\quad$ Yes & 125 & 59.2 \\
$\quad$ No & 86 & 40.8 \\
Requesting information about mode of delivery & \\
$\quad$ Yes & 172 & 81.5 \\
$\quad$ No & 39 & 18.5 \\
Preferred mode of delivery & & \\
Vaginal birth & 185 & 87.7 \\
Caesarean section & 16 & 7.6 \\
Physician must decide & 5 & 2.4 \\
No idea & 5 & 2.4 \\
\hline$\quad$ &
\end{tabular}

Table 3. Reasons of preferring vaginal delivery according to preferences for mode of delivery $(n=185)$

\begin{tabular}{lll}
\hline Reasons for Preferences $^{*}$ & n & $\%$ \\
\hline It is healthier for mother and infant & 180 & 85.3 \\
I will recover more quickly after birth & 177 & 83.9 \\
It would be more natural and non-interventional & 170 & 80.6 \\
It will be safer for mother and infant & 168 & 79.6 \\
I can breastfeed my baby sooner after birth & 164 & 77.7 \\
I will have less pain after birth & 162 & 76.8 \\
The birth will be easier & 146 & 69.2 \\
Being afraid of caesarean section/surgery & 85 & 40.3 \\
Physician or midwife/nurse's advice & 77 & 36.5 \\
Request of my family/partner & 66 & 31.3 \\
\hline
\end{tabular}

Note. ${ }^{*}$ Women's responses are more than one 
Table 4. Reasons of preferring caesarean section according to preferences for mode of delivery ( $n=16)$

\begin{tabular}{lll}
\hline Reasons for Preferences $^{*}$ & n & \% \\
\hline Fear of labor pain and thinking that caesarean section will be less painful & 11 & 73.3 \\
Birth in more clean and sterile conditions & 11 & 73.3 \\
Caesarean section causes less vaginal damage & 11 & 73.3 \\
Caesarean section is easier than vaginal birth & 9 & 66.7 \\
Caesarean is safer and healthier for the mother & 9 & 60.0 \\
Caesarean section does not affect later sexual life & 8 & 60.0 \\
Caesarean section is safer and healthier for the baby & 6 & 53.3 \\
Not to have negative vaginal delivery experience & 6 & 40.0 \\
Request of my family and partner & 5 & 40.0 \\
Having health problems in mother & 5 & 33.3 \\
Physician or midwife/nurse's advice & 5 & 33.3 \\
Due to the risk of development of postpartum urinary incontinence after vaginal delivery & 4 & 26.7 \\
Having baby with assisted reproductive techniques & 4 & 10 \\
Effects of mass media (television, radio, newspaper etc.) & 5 & 26.7
\end{tabular}

Note. ${ }^{*}$ Women's responses are more than one

Table 5. FCPPS mean scores of pregnant women according to preferences for mode of delivery $(\mathrm{n}=211)$

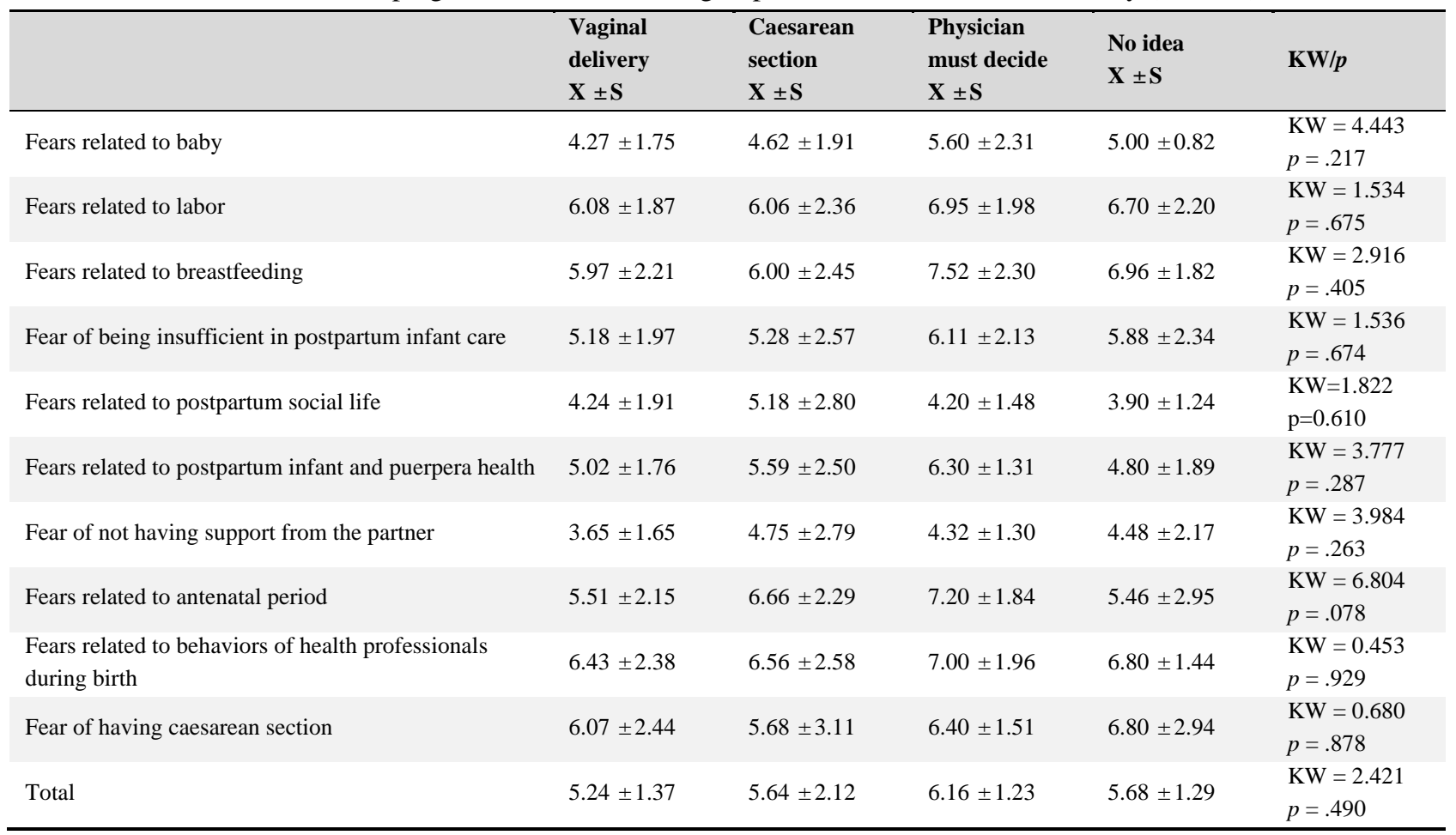

As shown in Fiqure 1, fear of childbirth and postpartum period levels were found $18.5 \%$ as low, $49.8 \%$ moderate, $28 \%$ high, and $3.7 \%$ very high, respectively (see Fiqure 1). As shown in Table 5, There was no statistically significant difference between FCPPS subscale and total mean scores according to pregnant women's preferences for mode of delivery $(p>.05)$ (see Table 5).

\section{DisCussion}

Women's preferences for mode of delivery can differ according to their expectations and experiences. However, peripartum attitudes, beliefs, fears, and anxieties are the most important factors that influence their preference for mode of delivery. In the perinatal care system, regardless of health and pregnancy conditions, women may decide to choose 
an obstetrician from the very beginning of their pregnancy, which affects their preference for mode of delivery. Some women are concerned about the health of postpartum babies, about survival during pregnancy or childbirth and about the effects of these changes on their marriage and family life. For this reason, it is important to determine the expectations of the pregnant women, preferences for mode of delivery, and their fear and anxiety of themselves and their babies.

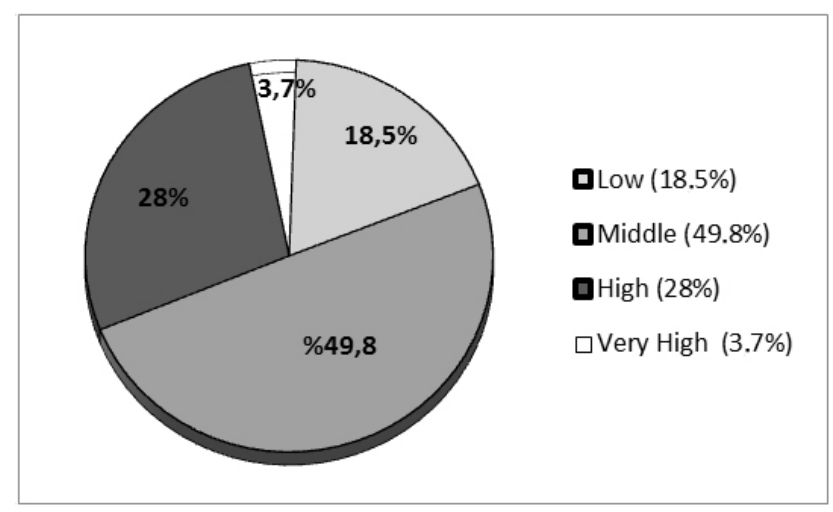

Figure 1. Distribution of pregnant women's fear of childbirth and postpartum period levels

$87.7 \%$ of primiparous pregnant women in this study have stated that they will prefer vaginal delivery (VD) if they have a chance to choose. Similar to our study findings, in other studies conducted in Turkey VD rates are high. They are $90 \%$ in study of Y1lmaz et al. ${ }^{[10]} 84 \%$ in Buyukbayrak et al., ${ }^{[34]} 78.8 \%$ in Karabulutlu, ${ }^{[35]} 77.3 \%$ in Vatansever and Okumuş. ${ }^{[36]}$ VD rates are also high in study of Pevzner et al. ${ }^{[37]}$ with $86.5 \%$, in Torloni et al. ${ }^{[9]}$ with $84.7 \%$ and in Dweik et al. ${ }^{[38]}$ with $88.4 \%$. Ryding et al. ${ }^{[39]}$ found that primaparous pregnant women of different countries (Germany, Iceland, Denmark, Estonia, Norway, Sweden) preferred VD $85.1 \%, 61.7 \%, 77.5 \%, 60.0 \%, 71.1 \%, 71.1 \%$, respectively. According to some studies, VD preference of pregnant Turkish women is higher. ${ }^{[10,37,39-41]}$

According to studies conducted in our country, the high rates of caesarean section while having a high rate of VD are due to the lack of education and information, the lack of support on vaginal delivery, and the effect of health professionals. Therefore, it is important to consider vaginal delivery preferences of women, supporting their decisions and having vaginal delivery unless caesarean section is indicated. As the gestational week progresses, women's preferences for mode of delivery may change. ${ }^{[40]}$ For this reason, their preferences for mode of delivery should be asked again. Vaginal delivery is quite beneficial to both mothers and infants. ${ }^{[42]}$

Primiparous pregnant women in this study stated that they would prefer VD because "it is healthier for mother and

Published by Sciedu Press infant", "they will recover more quickly after birth", "it is more natural and non-interventional", "the baby will start to breastfeed earlier", "they will have less pain after birth", "it will be safer for mother and infant" and "being afraid of caesarean section/surgery". Pevzner et al. ${ }^{[37]}$ found that $93 \%$ of mothers stated that VD was healthy, $88 \%$ it was healthy for infants, $34 \%$ it was natural, $29 \%$ caesarean delivery had more complication risk, and $13 \%$ stated that caesarean section should be performed only in the presence of a risk. Y1lmaz et al. ${ }^{[10]}$ also stated that women prefer VD for similar reasons and found that primiparity is a factor that reduces the risk of CS preference. Torloni et al. ${ }^{[9]}$ found that the main reasons for women preferring vaginal delivery were not to miss the first hours of the baby, the shorter hospitalization period, and the faster postpartum recovery. Pank et al. ${ }^{[40]}$ found that primiparous pregnant women prefer VD because of fast postpartum recovery, being natural, feeling the birth experience, less pain and being safer for mother and infant. According to the study of Mazzoni et al. ${ }^{[41]}$ carried out with nulliparous pregnant women, the first five reasons for preferring VD were found to be naturalcy, fast recovery, fear of surgery, feeling of birth experience, less pain and more safety.

In the studies conducted, women have stated that VD has advantages in preference for mode of delivery. It is important for women to know the benefits of VD to the mother and infant, their raising awareness, and to make conscious decisions.

Caesarean delivery can be life saving for mother and infant in case of medical necessity. However, caesarean section has much more health risks than benefits for both mother and infant when compared to vaginal delivery. The WHO has suggested that the caesarean delivery rate should be optimal 10\%-15\%. However, in the past 30 years, caesarean section rates have increased significantly even in our country. Caesarean section rates in the USA in 2014 were 31.6\%. ${ }^{\text {[43] }}$ Caesarean section is quite widespread in Turkey. According to data of recent Turkey Demographic and Health Survey (TDHS), caesarean section rate is $48 \%$ and $52 \%$ of first births are performed as caesarean section. ${ }^{[4]}$

The rate of pregnant women preferring CS in our study is 7.6\%. Similar results were obtained from studies of other countries which were Singapore 3.7\%, ${ }^{[45]}$ Sweden $8.7 \%{ }^{[46]}$ and Turkey $13.8 \% .{ }^{[36]}$ Pregnant women in our study preferred CS mostly because of "being afraid of labor pain and less pain in caesarean section (73.3\%)". Although labor pain is part of the physiological process, it is one of the most related factor with fear of childbirth. Studies show that those who have more fear of chilbirth are the ones who experience 
more labor pain and those who have more labor pain are the ones who have more fear of childbirth. "Preference for mode of delivery" of women is affected by their fear of childbirth. It is stated that fear of childbirth increases the rate of caesarean section and that most of women prefer caesarean section instead of vaginal delivery. ${ }^{[30]}$

According to the research results conducted abroad, $6 \%-10 \%{ }^{[47,48]}$ of the women who have fear of childbirth and $47.4 \%{ }^{[22]}$ of them according to the latest research done in our country have caesarean section due to fear of childbirth without any medical reason. Therefore, labor pain and fear of childbirth should be addressed in order to increase VD satisfaction, to strengthen mother-infant relationship, to improve positive breastfeeding, to reduce labor pain, oxytocin use, complicated births and caesarean section rates, and to decrease preference for caesarean section.

In this study, two other important reasons for preferring CS are its not causing vaginal damage $(73.3 \%)$ and not affecting sexual life negatively $(60 \%)$. In a similar study, women reported that they preferred CS because it would not damage vaginal zone $(67.1 \%)$ and that it would not affect the sexual life (36.8\%). ${ }^{[10]}$ In another qualitative study, women were also concerned that VD may harm the genital area, vagina and its aesthetic appearance, and that they may experience sexual problems. ${ }^{[49]}$ Therefore, it is important to address the fears of pregnant women and eliminate them. Pregnants should be encouraged to go to prenatal trainings so that they can be prepared to birth consciously and help them to decide their mode of delivery.

Almost half of primiparous pregnant women in our study $(49.8 \%)$ had moderate level of fear of childbirth and postpartum period. From FCPPS subscales, only fear of not having support from the partner after birth was low. Fears related to baby, fears related to labor, fears related to breastfeeding, fears of being insufficient in postpartum infant care, fears related to postpartum social life, fears related to postpartum infant and puerpera health, fears related to antenatal period, fears related to behaviors of health professionals during pregnancy and fear of caesarean section were at moderate level in pregnant women. Pregnant women's preferences for mode of delivery did not have an effect on their fear of chilbirh and postpartum period.

Although preference for mode of delivery does not affect women's fear of childbirth and postpartum period in our study, pregnant women have moderate level of fears related to different factors of childbirth and postpartum period. In studies conducted, fear of childbirth of pregnant women who participated in childbirth preparation classes were found to decrease, ${ }^{[32,50]}$ and to increasing the vaginal delivery preferences. ${ }^{[51]}$ In addition, counseling for women in prepregnancy, delivery and postpartum periods may also reduce the fear and anxiety of childbirth. It was determined that psychoeducation given by the specialized health professionals in the antenatal period may decrease the fear of childbirth of nulliparous women. It was also found that it increased adaptation to maternity and decreased postpartum depression. ${ }^{[52]}$ In addition to birth support, spousal support can be provided to pregnant women. In the study of Ganapathy ${ }^{[53]}$ and Hall et al., ${ }^{[54]}$ it was determined that spousal support reduced the fear of childbirth.

All healthcare professionals involved in birth have important responsibilities in reducing the fear of childbirth. However, it is necessary to provide the qualifications of health professionals in terms of lack of information about the interventions to reduce the fear of childbirth. Therefore, training of health professionals is very important. ${ }^{[26]}$ Health professionals should counsel and guide pregnant women by considering their emotional changes and fears during pregnancy, birth and puerperium periods. By alleviating the fear and anxieties of the pregnant women, their interest in vaginal delivery can increase and this can contribute to the reduction of caesarean rates. One of the limitations of the study is that it can not be generalized to all pregnant women because it was done in a single province and in a single hospital. The second limitation is the small number of samples.

\section{Conclusions}

Most of primiparous women stated their preference for mode of delivery as vaginal delivery. Pregnant women's fear of childbirth and postpartum period are at moderate level and their preferences for mode of delivery do not affect their fear of childbirth and postpartum period. Taking into consideration pregnant women's preferences for mode of delivery unless it requires medical indication, supporting their preferences, alleviating their fear of childbirth and postpartum period are extremely important in increasing their satisfaction and adaptation to pregnancy, childbirth and to postpartum period.

Health professionals should be effective in pregnant women's active participation and making conscious decisions about their preferences for mode of delivery. More supportive services should be provided in health services given to pregnant women.

\section{CONFlicts OF InTEREST Disclosure}

The authors declare they have no conflicts of interest. 


\section{REFERENCES}

[1] World Health Organization. WHO explanation on cesarean birth rates. 2015. Available from: http://apps.who.int/iris/bits tream/10665/161442/11/WHO_RHR_15.02_tur.pdf

[2] Coalition for Improving Maternity Services. Ten steps of the motherfriendly childbirth initiative for mother-friendly hospitals, birth centers, and home birth services. 1996. Available from: http: //www.motherfriendly.org/MFCI/steps.html

[3] Eskicioğlu F, Hasdemir PS, Çelik H, et al. The effect of health policies on physicians' decisions to perform caesarean sections: evaluation of a secondary health institution. Pamukkale Tip Dergisi. 2014; 7(2): 119-123.

[4] Yapça ÖE, Karaca İ, Çatma T. How can we reduce the increasing primary cesarean rates? evaluation of our 3-year data of cesarean sections. İstanbul Kanuni Sultan Süleymen Tıp Dergisi. 2015; 7(3): 97-102.

[5] Türkiye Sağlık Bakanlığı. 2017. Available from: https://www.sa glik.gov.tr/TR

[6] Aslam MF, Gilmour KR, Fawdry DS. Who wants a caesarean section? a study of woman's personel experience of vaginal and caesarean delivery. Journal of Obstetrics and Gynaecology. 2003; 23(4): 364366. PMid: 12881072. https://doi.org/10.1080/0144361031 000119493

[7] Fenwick J, Staff L, Gamble J, et al. Why do women request caesarean section in a normal, healthy first pregnancy? Midwifery. 2010; 26 : 394-400. PMid: 19117644. https ://doi.org/10.1016/j.midw .2008 .10 .011

[8] Onderoğlu L, Karamursel BS, Taşkıran C. Obstetrikal operasyonlar: sezaryen, "Jinekolojik ve Obstetrikal Cerrahi" [Obstetrical operations: caesarean section? "Gynecological and Obstetrical Surgery"]. Guner H, e.d. Ankara: Guneş Kitabevi; 2005. 1549-1480 p.

[9] Torloni MR, Betrán AP, Montilla P, et al. Do Italian women prefer cesarean section? Results from a survey on mode of delivery preferences. BMC Pregnancy Childbirth. 2013; 13: 78. PMid: 23530472. https://doi.org/10.1186/1471-2393-13-78

[10] Yilmaz SD, Bal MD, Beji NK, et al. Women's preferences of method of delivery and influencing factors. Iran Red Crescent Med J. 2013; 15(8): 683-689. PMid: 24578835. https://doi.org/10.5812/ ircmj. 11532

[11] İğde FA. Sezaryen sonrası normal vajinal doğum [Normal vaginal birth after cesarean section]. Sürekli Tıp Eğitimi Dergisi. 2004; 13(4): 137-139.

[12] Konakcı S, Kılıc B. Sezaryen ile doğumlar artıyor [Increase births with cesarean section]. Surekli Tıp Eğitimi Dergisi. 2002; 8(11): 286-288.

[13] Park CS, Yeoum SG, Choi ES. Study of subjectivity in the perception of cesarean birth. Nursing and Health Sciences. 2005; 7(1): 3-8. PMid: 15670000. https://doi.org/10.1111/j.1442-201 8.2005.00206.x

[14] Konakcı SK, Kılıc B. İzmir'de sezaryen ile doğum sıklığı ve buna etki eden faktörler [Prevalence and affecting factors for cesarean section deliveries in Izmir]. Turkiye Klinikleri Obstetrik-Jinekoloji. 2004; 14: 88-95.

[15] İldingsson I, Rådestad I, Rubertsson C, et al. Few women wish to be delivered by caesarean section. BJOG. 2002; 109(6): 618-613. https://doi.org/10.1111/j.1471-0528.2002.01393.x

[16] Janssen PA, Ryan EM, Etches DJ, et al. Outcomes of planned hospital birth attended by midwives compared with physicians in British Columbia. Birth. 2007; 34(2): 140-147. PMid: 17542818. https://doi.org/10.1111/j.1523-536X.2007.00160.x

[17] Kringeland T, Daltveit AK, Moller A. What characterizes women in Norway who wish to have a caesarean section? Scandinavian
Journal of Public Health. 2009; 37: 364-371. PMid: 19372232 https://doi.org/10.1177/1403494809105027

[18] Ecker J. Elective cesarean delivery on maternal request. Journal of the American Medical Association. 2013; 309(18): 1930-1936. PMid: 23652524. https://doi.org/10.1001/jama.2013.3982

[19] McCourt C, Weaver J, Statham H, et al. Elective cesarean section and decision making. A critical review of the literature. Birth. 2007; 34(1): 65-79. PMid: 17324181. https://doi.org/10.1111/j. 1523-536X . 2006.00147.x

[20] Gamble J, Creedy D, McCourt C, et al. A critique of the literatüre on women's request for a cesarean section. Birth. 2007; 34(4): 331340. PMid: 18021149. https://doi.org/10.1111/j.1523-5 36X.2007.00193.x

[21] Karlström A, Rådestad I, Eriksson C, et al. Cesarean section without medical reason 1997-2006: a Swedish register study. Birth. 2010; 37(1): 11-22. PMid: 20402717. https://doi.org/10.1111/j . 1523-536X. 2009.00373.x

[22] Ergöl Ş, Kürtüncü M. Bir Üniversite hastanesinde kadınların sezaryen doğum tercihlerini etkileyen faktörler [Factors affecting women's preferences for cesarean birth in a University Hospital]. Hacettepe Üniversitesi Hemşirelik Fakültesi Dergisi. 2014; 26-34.

[23] Storkesen H, Eberhard-Gran M, Garthus-Niegel S, et al. Fear of childbirth; the relation to anxiety and depression. Acta Obstetricia et Gynecologica Scandinavica. 2012; 91: 237-242. PMid: 22085403. https://doi.org/10.1111/j.1600-0412.2011.01323.x

[24] Jokić-Begić N, Žigić L, Nakić Radoš S. Anxiety and anxiety sensitivity as predictors of fear of childbirth: different patterns for nulliparous and parous women. Journal of Psychosomatic Obstetrics \& Gynecology. 2014; 35(1): 22-28. PMid: 24328559. https : //doi.org/10.3109/0167482X.2013.866647

[25] Ternström E, Hildingsson I, Haines H, et al. Higher prevalence of childbirth related fear in foreign born pregnant women findings from a community sample in Sweden. Midwifery. 2015; 31(4): 445 450. PMid: 25529841.https ://doi.org/10.1016/j.midw. 201 4.11.011

[26] Cicek O, Mete S. A common problem: fear of childbirth. DEUHFED 2015; 8(4): 263-268.

[27] Gözükara F, Eroğlu K. İlk doğumunu yapmış kadınların (primipar) doğum şekline yönelik tercihlerini etkileyen faktörler [Factors that effect the choices of primipars on the mode of delivery]. H.Ü Sağlık Bilimleri Fakültesi Hemşirelik Dergisi. 2008; 15(2): 32-46.

[28] Hildingsson I, Thomas J. Maternity services from women's perspectives in Sweden: processes, problems and solutions. Journal of Midwifery \& Women's Health. 2007; 52(2): 126-133. PMid: 17336818. https://doi.org/10.1016/j.jmwh.2006.10.023

[29] Kingdon C, Neilson J, Singleton V, et al. Choice and birth method: mixedmethod study of caesarean delivery for maternal request. Biritish Journal of Obstetrics and Gynaecology. 2009; 116(7): 886895. PMid: 19385961. https://doi.org/10.1111/j.1471-0 528.2009.02119.x

[30] Romero ST, Coulson CC, Galvin SL. Cesarean delivery on maternal request: a western North Carolina perspective. Matern Child Health Journal. 2012; 16(3): 725-734. PMid: 21400201. https : //doi.org/10.1007/s10995-011-0769-x

[31] Thomas J, Paranjothy S. The national sentinel caesarean section audit report. London: Royal College of Obstetricians and Gynecologists. 2001. Available from: https://www.rcog.org.uk/globalassets/documents /guidelines/researchaudit/nscs_audit.pdf

[32] Karabulut O, Coşkuner PD, Doğan MY, et al. Does antenatal education reduce fear of childbirth? Int Nurs Rev. 2016 Mar; 63(1): 60-67. PMid: 26612181. https://doi.org/10.1111/inr.12223 
[33] Kitapçığlu G, Yanıkkerem E, Sevil Ü, et al. Gebelerde doğum ve postpartum döneme ilişkin endişeler; bir ölçek geliştirme ve validasyon çalışması [Fear of childbirth and the postpartum period: a scale development and validation study]. Adnan Menderes Üniversitesi Tıp Fakültesi Dergisi. 2008; 9(1): 47-54.

[34] Buyukbayrak EE, Kaymaz O, Kars B, et al. Caesarean delivery or vaginal birth: Preference of Turkish pregnant women and influencing factors. Journal of Obstetrics and Gynaecology. 2010; 30(2): 155 158. PMid: 20143975. https ://doi.org/10.3109/0144361090 3461436

[35] Karabulutlu Ö. Kadınların doğum şekli tercihlerini etkileyen faktörler [Identifying the women's choice of delivery methods of and the factors that affect them]. İ.U..F.N. Hemşirelik. Dergisi. 2012; 20(3) 210-218.

[36] Vatansever Z, Okumuş H. Gebelerin doğum şekline karar verme durumlarının incelenmesi. DEUHYO ED. 2013; 6(2): 82-87.

[37] Pevzner L, Preslicka C, Bush MC, et al. Women's attitudes regarding mode of delivery and cesarean delivery on maternal request. The Journal of Maternal-Fetal and Neonatal Medicine. July 2011; 24(7): 894-899. PMid: 21635180. https ://doi.org/10.3109/147670 58.2010 .531797

[38] Dweik D, Grrasek E, Töreki A, et al. Women's antenatal preferences for delivery route in a setting with high cesarean section rates and a medically dominated maternity system. Acta Obstetricia et Gynecologica Scandinavica. 2014; 93: 408-415. PMid: 24575805. https://doi.org/10.1111/aogs. 12353

[39] Ryding EL, Lukasse M, Krisjansdottir H, et al. Pregnant women's preference for cesarean section and subsequent mode of birth a six-country cohort study. Juornal of Psychosomatic Obstetrics \& Gynecology. 2016; 37(3): 75-83. PMid: 27269591. https: //doi.org/10.1080/0167482X.2016.1181055

[40] Pang MW, Leung TN, Lau TK, et al. Impact of first childbirth on changes in women's preference for mode of delivery: followup of a longitudinal observational study. Birth. 2008; 35(2): 121128. PMid: 18507583 . https : //doi .org/10.1111/j.1523-536 X. 2008.00225.x

[41] Mazzoni A, Althabe F, Gutierrez L, et al. Women's preferences and mode of delivery in public and private hospitals: a prospective cohort study. BMC Pregnancy Childbirth. 2016; 16(1): 34. PMid: 26857448 https://doi.org/10.1186/s12884-016-0824-0

[42] Dietz HP, Campbell S. Toward normal birth-but at what cost? Am J Obstet Gynecol. 2016; 215(4): 439-444. PMid: 27131590. https://doi.org/10.1016/j.ajog.2016.04.021

[43] Hehir MP, Ananth CV, Siddiq Z, et al. Cesarean delivery in the United States 2005 through 2014: a population-based analysis using the Robson 10- Group Classification System. American Journal of Obstetrics \& Gynecology. 2018; 219(1): 105.e1-105.e11. PMid: 29655965. https://doi.org/10.1016/j.ajog.2018.04.012
[44] Türkiye Nüfus Sağlık Araştırması 2013 Hacettepe Üniversitesi Nüfus Etütleri Enstitüsü Ankara, Türkiye [Turkey Demographic and Health Survey 2013 Hacettepe University Institute of Population Studies]. Available from: http://www.hips.hacettepe.edu.tr/tnsa20 13/rapor/TNSA_2013_ana_rapor.pdf

[45] Chong ESY, Mongelli M. Attitudes of Singapore women toward cesarean and vaginal deliveries. International journal of gynaecology and obstetrics: the official organ of the International Federation of Gynaecology and Obstetrics. 2003; 80(2): 189-194. https : //doi.org/10.1016/S0020-7292(02)00391-0

[46] Haines H, Rubertsson C, Pallant JF, et al. Womens' attitudes and beliefs of childbirth and association with birth preference: a comparison of a Swedish and an Australian sample in mid-pregnancy. Midwifery. 2012; 28(6): e850-6. PMid: 22098781. https : //doi . org/10.1016/j.midw.2011.09.011

[47] Storkesen, H, Eberhard-Gran M, Garthus-Niegel S, et al. Fear of childbirth; the relation to anxiety and depression. Acta Obstetricia et Gynecologica Scandinavica. 2012; 91: 237-242. PMid: 22085403. https ://doi.org/10.1111/j.1600-0412.2011.01323.x

[48] Sydsjö G, Sydsjö A, Gunnervik C, et al. Obstetric outcome for women who received individualized treatment for fear of childbirth during pregnancy. Acta Obstetricia et Gynecologica Scandinavica. 2012; 91 : 44-49. PMid: 21787365. https ://doi .org/10.1111/j.1600-0 412.2011.01242.x

[49] Sercekus P, Okumus H. Fears associated with childbirth among nulliparous women in Turkey. Midwifery. 2009; 25(2): 155-162. PMid: 17600599. https://doi.org/10.1016/j.midw.2007.02.005

[50] Serçekuş P, Mete S. Effects of antenatal education on maternal prenatal and postpartum adaptation. Journal of Advanced Nursing. 2010; 66(5): 999-1010. PMid: 20337796. https://doi.org/10.1111/ j.1365-2648.2009.05253.x

[51] Mete S, Çiçek Ö, Tokat MA, et al. The effect of childbirth preparation classes on fear of childbirth, birth preference and preparation of labor. Turkiye Klinikleri J Nurs Sci. 2017; 9(3): 201-206. https : //doi.org/10.5336/nurses.2016-53977

[52] Rouhe H, Salmela-Aro K, Toivanen R, et al. Group psychoeducation with relaxation for severe fear of childbirth improves maternal adjustment and childbirth experience-a randomised controlled trial. Journal of Psychosomatic Obstetrics \& Gynecology. 2015; 36 (1): 1-9. PMid: 25417935. https ://doi.org/10.3109/0167482X.2 014.980722

[53] Ganapathy T. Tokophobia among first time expectant fathers. International Journal of Psychiatric Nursing. 2015; 1(1): 99-106. https://doi.org/10.5958/2395-180X.2015.00024.9

[54] Hall W, Hauck Y, Carty E, et al. Childbirth fear, anxiety, fatigue, and sleep deprivation in pregnant women. Journal of Obstetric and Gynecology Neonatal Nursing. 2009; 38: 567-576. PMid: 19883478. https://doi.org/10.1111/j.1552-6909.2009.01054.x 